\title{
Social Interactions between Teachers and Students: A Study Addressing Associations and Predictions ${ }^{1}$
}

\author{
Marília Mariano ${ }^{2}$,Alessandra Turini Bolsoni-Silva ${ }^{3}$ \\ ${ }^{2}$ Universidade Estadual Paulista, São Paulo-SP, Brazil \\ ${ }^{3}$ Universidade Estadual Paulista, Bauru-SP, Brazil
}

\begin{abstract}
Interactions between teachers and students impact children's academic and social learning. This study's objective was to identify associations and predictions between variables concerning social educational skills, negative educational practices, behavior problems and the social skills of students differentiated by schooling, clinical indicators of behavior problems, and gender. A total of 283 children and their teachers from the public schools participated in the study, who answered questionnaires and participated in a semi-structured interview. Correlation and regression statistical analysis were performed. All the groups presented positive correlations between social educational skills, children's social skills, negative educational practices, and behavior problems. Behavior problems and social skills presented predictive values among preschoolers. The aforementioned variables, together with positive and negative educational practices, presented predictive values among school children. The conclusion is that teachers can be a protective factor for children's development, but this requires planning.
\end{abstract}

Keywords: behavioral disorders, social skills, teacher attitudes

\section{Interações Sociais entre Professores e Alunos: Um Estudo de Associações e Predições}

Resumo: Interações entre professores e alunos produzem impactos nas aprendizagens acadêmica e social das crianças. Este estudo objetivou identificar associações e predições entre variáveis de habilidades sociais educativas, práticas educativas negativas, problemas de comportamentos e habilidades sociais infantis de alunos diferenciados pela escolaridade, indicadores clínicos de problemas de comportamento e sexo. Participaram do estudo 283 crianças da rede pública de ensino e seus professores que responderam a questionários e participaram de entrevista semiestruturada. Conduziram-se análises estatísticas de correlação e regressão. Em todos os grupos houve correlações positivas entre habilidades sociais educativas e infantis e práticas educativas negativas e problemas de comportamento. Para pré-escolares, as queixas de problemas e as habilidades sociais apresentaram valores preditivos. Para escolares, as variáveis supracitadas, somadas às práticas educativas positivas e negativas, indicaram valores preditivos. Conclui-se que professores podem atuar como fator protetivo ao desenvolvimento infantil, o que requer planejamento.

Palavras-chave: distúrbios do comportamento, habilidades sociais, atitudes do professor

\section{Interacciones Sociales entre Profesores y Alumnos: Un Estudio de Asociaciones y Predicciones}

\begin{abstract}
Resumen: Interacciones entre profesores y alumnos producen impactos en los aprendizajes académicos y sociales de los niños. El objetivo de este estudio fue identificar asociaciones y predicciones entre variables de habilidades sociales educativas, prácticas educativas negativas, problemas conductuales y habilidades sociales infantiles, de alumnos diferenciados por la escolaridad, indicadores clínicos de problemas conductuales y sexo. Participaron del estudio 283 niños y sus profesores, de la red pública de enseñanza, que contestaron cuestionarios y participaron de entrevista semiestructurada. Se llevaron a cabo análisis estadísticos de correlación y regresión. En todos los grupos, fueron encontradas correlaciones positivas entre habilidades sociales educativas y infantiles y prácticas educativas negativas y problemas conductuales. Para preescolares, las quejas de problemas y las habilidades sociales presentaron valores predictivos. Para escolares, estas variables, sumadas a las prácticas educativas positivas y negativas, indicaron valores predictivos. Se concluye que profesores pueden actuar como factor protector al desarrollo, lo que demanda planeamiento.
\end{abstract}

Palabras clave: trastornos de la conducta, habilidades sociales, actitudes del profesor

${ }^{1}$ Paper derived from the first author's Master's thesis, under the supervision of the second author, defended in the Graduate Program in Psychology of Development and Learning at the Universidade Estadual Paulista. Support: São Paulo Research Foundation (FAPESP, Grant No. 2013/08955-0).
Correspondence address: Marília Mariano. Universidade Estadual Paulista. Faculdade de Ciências. Programa de Pós-Graduação em Psicologia do Desenvolvimento e Aprendizagem. Av. Eng. Luiz Edmundo Carrijo Coube, 14-01, São Paulo-SP, Brazil. CEP 01.049-010.E-mail: mariano.mrl@gmail.com 
Behavioral problems with the potential to become risk factors for mental diseases during adulthood, such as depression, can be identified during childhood in the school environment (Patterson, Reid, \& Dishion, 1992; Reinke, Eddy, Dishion, \& Reid, 2013). Behavior problems are classified as externalizing problems, characterized by disobedience, opposition, headed temperament, robbery and escape, or as internalizing problems, such as shyness, fear and social isolation (Achenbach \& Edelbrock, 1978; CasaliRobalinho, Z.A.P. Del Prette, \& A. Del Prette, 2015).

Additionally, these behaviors occur concomitantly with a deficit in the acquisition and use of social skills (Berry \& O'Connor, 2010; Bolsoni-Silva \& Mariano, 2014; CasaliRobalinho et al., 2015; Gomes \& Pereira, 2014; Patterson et al., 1992). These skills represent behaviors that contribute to the quality and effectiveness of social interactions and tend to expand one's behavioral repertoire, as they promote new interpersonal situations in different settings, and also compete with problem behaviors (Bolsoni-Silva \& Carrara, 2010; Bub, Mccartney, \& Willett, 2007; Casali-Robalinho et al., 2015). Thus, social skills tend to favor development (protective factor), as opposed to behaviors that indicate problems and tend to be harmful to one's development (Bolsoni-Silva \& Mariano, 2014; Bub et al., 2007; Casali-Robalinho et al., 2015; O'Connor, Dearing, \& Collins, 2011; Silver, Measelle, Armstrong, \& Essex, 2010).

In the school setting, patterns of behavior problems tend to progress and then stabilize over the course of development and may lead to social rejection and academic failure (Bray \& Leonardo, 2011; O'Connor et al., 2011; Picado \& de Rose, 2009). Empirical studies assessing behavior problems and social skills in schools show that patterns are associated with: (1) the gender of children: boys more frequently than girls present behavior problems (Baker, Grant, \& Morlock, 2008; Gomes \& Pereira, 2014; Pizato, Marturano, \& Fontaine 2014; Silver et al., 2010); (2) level of education: children who attended early child education seem to develop better social repertoires (Pereira, Marturano, Gardinal-Pizato, \& Fontaine, 2011; Pizato et al., 2014) or behavior problems may progress together with the progression of educational levels, as the environment becomes more complex and more demanding in social and academic terms (Buyse, Verschueren, Doumen, Damme, \& Maes, 2008); (3) interactions with colleagues and teachers: children with behavioral problems establish negative, conflicting relationships in which there is mutual anger and a more restricted repertoire of social skills (Baker et al., 2008; Bolsoni-Silva, Marturano, \& Freiria, 2010; Kettler, Elliott, Davies, \& Griffin, 2011; Kim, Doh, Hong, \& Choi, 2010; Pizato et al., 2014; Silver et al., 2010). Additionally, the study by Guerra et al. (2015) reports that most children who were referred to a specialized educational center presented externalizing problems, while a minority were diagnosed with a condition that required special education (for example, Down Syndrome or Autistic Spectrum Disorder), showing there is a great demand related to behavior problems in special education settings.

In regard to the behavior of teachers, studies (Baker et al., 2008; Bolsoni-Silva \& Mariano, 2014; Silver et al., 2010) indicate that teachers tend to more frequently punish children who have behavior problems, while they seem to be more communicative and affectionate with children without behavior problems (Baker et al., 2008; Bolsoni-Silva \& Mariano, 2014). Bolsoni-Silva and Mariano (2014) assert that negative educational practices (for example, yelling, threatening, punishing) may encourage aggressive behavior among students and intensify problem behaviors instead of minimizing them. In turn, positive practices or social educational skills (for example, praising, greeting, thanking) are associated with the development of children's social skills. Additionally, relationships characterized by closeness and affection between teacher and student predicted lower rates of behavior problems and acted as protective factors, preventing problems from becoming stable (Baker et al., 2008; O’Connor et al., 2011; Silver et al., 2010).

Given the previous discussion, there seem to be different types of interactions that are established between teachers and students in the school setting, promoting different types of stimuli and learning (Baker et al., 2008; Bolsoni-Silva \& Mariano, 2014; Silver et al., 2010). Despite its social relevance, few Brazilian empirical studies investigate this topic, failing to address the mutual influence of interactions established with teachers on children's repertoire of behaviors, comparing the children's different educational levels and gender (Bolsoni-Silva et al., 2010; Bolsoni-Silva \& Mariano, 2014; Casali-Robalinho et al., 2015; Pizato et al., 2014). The reason is that studies either address behavioral problems and/or children's social skills in a given school period (Bolsoni-Silva et al., 2010; Casali-Robalinho et al., 2015; Pereira et al., 2011; Pizato et al., 2014) or associate the children's behavior problems and/or social skills with the teachers' repertoire, but employ small samples (BolsoniSilva \& Mariano, 2014; Picado \& de Rose, 2009). This study, in contrast, is concerned with controlling multiple variables and comparing groups according to educational level and gender in a representative sample, which allows greater generalization and predictive statistical analysis. Thus, this study's objective was to identify associations and predictive values among categories of behaviors present in the social interactions established between teachers and students according to the children's characteristics: educational level (preschool or school); gender (girls or boys); and behavioral problems indicators (clinical or non-clinical behavior problems). The teachers' behaviors were classified as social and educational skills or negative educational practices, while the students' behaviors were classified as children's behavioral problems or children's social skills.

\section{Method}

\section{Participants}

A total of 283 children and their respective teachers from public schools located in a city in the Midwest region of the state of São Paulo, Brazil composed the sample: 113 were 
preschool-aged children attending early child education and 170 were attending primary school; 169 were boys and 114 were girls. The preschool children were aged between three and six years old (3.98 years old on average, with a standard deviation of 0.90 ) and the children attending primary school were aged between six and 12 years old ( 8.33 years old on average and standard deviation of 1.70). Only one of the preschool teachers was male, while the average age was 43 years old (standard deviation of 5.92, ranging from 26 to 60 years of age). In regard to education, $95 \%$ reported having a bachelor's degree, while four teachers reported incomplete undergraduate studies and two had completed high school. Among the 113 preschool teachers, 84 taught in one school only, while 28 taught in two schools and one taught in three schools. Among the 170 primary school teachers, 13 were male, aged 36 years old on average (standard deviation of 7.99). In terms of workload, 63 teachers taught in one school only, while 99 worked in two schools and eight teachers taught in three different schools. All the primary school teachers had a bachelor's degree and two reported graduate studies.

\section{Instruments}

Teacher's Report Form - TRF (Achenbach, 1991). This questionnaire enables categorizing the children's behavior repertoire from the perspective of teachers. It consists of an empirically validated assessment with good psychometric properties and high reliability index $(0.92)$ and can be used with children and teenagers (Achenbach, 1991; Bordin et al., 2013).

Its results enable identifying the profile of children, which can be classified for behavior problems in the categories of clinical, borderline or nonclinical. In this study, the criterion for a child to be included in the clinical group was obtaining a borderline and/or clinical score on any of the test scales (divided into externalizing, internalizing and total behavior).

Roteiro de Entrevista de Habilidades Sociais Educativas para Professores - RE-HSE-Pr (Social Skills Interview Script for Teachers) adapted by Mariano (2011). This instrument was adapted from the Roteiro de Entrevista de Habilidades Sociais Educativas de Pais - RE-HSE-P (Educational Social Skills Interview Script for Parents) (Bolsoni-Silva, Loureiro, \& Marturano, 2016), which presents satisfactory psychometric indexes (internal consistency with a Cronbach's alpha coefficient of 0.87). This interview script is intended to describe the interactions established between teachers and students based on the spontaneous responses of teachers to 12 questions/suggestions, which are divided into additional questions, enabling the description of the topography and frequency of the behaviors of both teachers and students. This instrument is currently undergoing validation. The material collected by the instrument can be organized into four categories: (1) Educational social skills, which refers to answers such as "talking to the student, monitoring tasks, praising, feeling important, safe"; (2) Negative educational practices, which refers to answers such as "removing the student from the classroom, punishing, yelling/talking too loudly, ignoring inappropriate behaviors, abandoning the situation, feeling bad"; (3) Children's Social Skills, which refers to behaviors such as "praising, obeying, paying attention, explaining why she/he acted in a certain way"; and finally, category (4) Behavioral Problems, which includes "hitting, fighting, retorting, isolation, lack of interest, crying".

Questionário de Respostas Socialmente Habilidosas (versão para professores) - QRSH-Pr (Questionnaire of Socially Skillful Responses - Teachers' version) (BolsoniSilva, Marturano, \& Loureiro, 2009). This instrument's objective is to identify children's social skills through 24 statements. The points are totaled and result in the child's total score. Some examples of the statements that compose the instrument are: "makes requests", "seeks your attention", "takes the initiative", "negotiates and persuades other people of their point of view", "participates in groups for games and projects in the classroom". The study by Bolsoni-Silva et al. (2009), which investigates the instrument's psychometric properties, reports satisfactory internal consistency (alpha equal 0.82 ) and predictive validity.

\section{Procedure}

Data collection. The early childhood education programs and elementary public schools were contacted to invite teachers to participate in the study and obtain the consent of families. The teachers who consented to participate in the study signed free and informed consent forms and were asked to nominate two children: one who they considered to have behavior problems and one without behavior problems. The teachers completed the instruments considering both children. Feedback included talks and the distribution of informational booklets addressing educational practices and child behaviors, in addition to a report of the study's results.

Data analysis. Data were characterized according to the instructions provided in the instruments and then submitted to correlation statistical analysis (Person's coefficient) and Binary Logistic Regression. In order to perform more precise correlation analysis, and control for a greater number of variables, we opted to divide the total sample into subgroups according to level of education, gender, and behavior problems. Meanwhile, two subsets of data were created according to the education criterion: preschool and school children, and each subset was divided according to the variables of gender and behavior problems. Hence, both for the preschool and school children: (1) the categories contained in the social skills interview and those contained in the questionnaire of social skills responses were correlated for the group of boys; (2) the categories contained in the social skills interview and those contained in the questionnaire of social skills responses were correlated for the group of girls; (3) again, the categories contained in the social skills interview and those contained in the questionnaire of social skills responses were correlated for the clinical group with behavior problems; and (4) the 
categories of both instruments were also correlated for the non-clinical group. The total scores obtained in both instruments were used in the Binary Logistic Regression, considering the children's gender for the two subsets of data, according to school level (preschool or school children). The five aforementioned categories composed the initial regression model and the dependent variable was the clinical or non-clinical classification for behavior problems, which was supported by the result obtained in the Teachers' Report Form. The level of significance adopted was $5 \%$ for univariate analysis and $10 \%$ for the multivariate analysis.

\section{Ethical Considerations}

The study was approved both by the Secretary of Education in the city where the study was conducted and by the Institutional Review Board at the hosting university (protocol No. 2567/46/01).

\section{Results}

This first section presents the results concerning correlations among educational social skills, negative educational practices, children's social skills and behavior problems of preschool and school children according to gender (Table 1, Table 3) and clinical indicators for behavior problems (Table 2, Table 4). The second section presents the results obtained in the Binary Logistic Regression for both groups of students (Table 5).

Table 1 presents the correlations between the different instruments applied to both preschool and school children, considering gender differences.

Table 1

Analysis of Correlation of Scores Obtained in the Subcategories of the Instruments Completed by Teachers Concerning their Educational Practices with Preschool Students According to Gender

\begin{tabular}{|c|c|c|c|c|c|c|c|c|c|c|c|c|c|c|c|c|}
\hline & & 1 & 2 & 3 & 4 & 5 & 6 & 7 & 8 & 9 & 10 & 11 & 12 & 13 & 14 & 15 \\
\hline \multirow{4}{*}{$\begin{array}{l}\text { Social } \\
\text { Skills } \\
\text { Interv } \\
\text { (SES) }\end{array}$} & 1 & - & .01 & .09 & $.80^{* *}$ & .08 & -.01 & .14 & .12 & $.22^{*}$ & .14 & $.24^{*}$ & .2 & -.07 & .21 & -.11 \\
\hline & 2 & -.2 & - & -.15 & .08 & .10 & $.29^{*}$ & .06 & .15 & .06 & -.01 & .03 & .20 & -.08 & .12 & .02 \\
\hline & 3 & $.32^{* *}$ & -.12 & - & $.25^{*}$ & -.12 & -.16 & $-.41^{* *}$ & $-.28^{*}$ & .20 & .14 & .21 & -.15 & -.10 & -.18 & $.25^{*}$ \\
\hline & 4 & $.83^{* *}$ & .03 & $.42^{* *}$ & - & .02 & .12 & .10 & .07 & $.31^{*}$ & $.26^{*}$ & $.36^{* *}$ & .12 & -.02 & .18 & .03 \\
\hline \multirow{4}{*}{$\begin{array}{l}\text { Social } \\
\text { Skills } \\
\text { Interv } \\
\text { (NEP) }\end{array}$} & 5 & -.18 & .03 & -.14 & -.02 & - & .12 & $.32^{* *}$ & $.90^{* *}$ & -.20 & .07 & -.10 & $.66^{* *}$ & $.23^{*}$ & $.49^{* *}$ & -.13 \\
\hline & 6 & -.09 & $-.23^{*}$ & -.06 & -.10 & .19 & - & .16 & $.31^{* *}$ & -.04 & -.01 & -.04 & $.23^{*}$ & -.01 & .21 & .17 \\
\hline & 7 & -.14 & -.12 & $-.25^{*}$ & -.10 & $.60^{* *}$ & $.60^{* *}$ & - & $.67^{* *}$ & $-.26^{*}$ & -.10 & $-.23^{*}$ & $.48^{* *}$ & $.25^{*}$ & $.51^{* *}$ & -.18 \\
\hline & 8 & -.18 & -.05 & -.19 & -.06 & $.92^{* *}$ & $.48^{* *}$ & $.84^{* *}$ & - & $-.27^{*}$ & .01 & -.17 & $.73^{* *}$ & $.27^{*}$ & $.61^{* *}$ & -.14 \\
\hline \multirow{3}{*}{$\begin{array}{l}\text { Social } \\
\text { Skills } \\
\text { Interv } \\
\text { (CSS) }\end{array}$} & 9 & $.25^{*}$ & .11 & -.10 & $.27^{*}$ & -.12 & -.17 & -.17 & -.16 & - & $.29^{*}$ & $.89^{* *}$ & $-.34^{* *}$ & $-.59^{* *}$ & $-.50^{* *}$ & $.44^{* *}$ \\
\hline & 10 & $.29^{*}$ & .15 & -.14 & $.35^{* *}$ & .18 & -.18 & .03 & .11 & $.37^{* *}$ & - & $.68^{* *}$ & -.07 & $-.37^{* *}$ & $-.26^{*}$ & $.28^{*}$ \\
\hline & 11 & $.33^{* *}$ & .14 & -.14 & $.35^{* *}$ & -.01 & -.21 & -.11 & -.07 & $.91^{* *}$ & $.71^{* *}$ & - & $-.29^{*}$ & $-.62^{* *}$ & $-.50^{* *}$ & $.46^{* *}$ \\
\hline \multirow{3}{*}{$\begin{array}{c}\text { Social } \\
\text { Skills } \\
\text { Interv } \\
\text { (BP) }\end{array}$} & 12 & -.01 & -.10 & .02 & -.08 & $.40^{* *}$ & .11 & $.53^{* *}$ & $.47^{* *}$ & $-.35^{* *}$ & -.05 & $-.29^{*}$ & - & $.22^{*}$ & $.82^{* *}$ & $-.25^{*}$ \\
\hline & 13 & .03 & -.18 & -.03 & .01 & $.26^{*}$ & $.23^{*}$ & $.30^{*}$ & $.31^{* *}$ & $-.49^{* *}$ & $-.31^{* *}$ & $-.50^{* *}$ & $.31^{* *}$ & - & $.60^{* *}$ & $-.55^{* *}$ \\
\hline & 14 & -.01 & -.16 & -.01 & -.07 & $.41^{* *}$ & $.23^{*}$ & $.52^{* *}$ & $.50^{* *}$ & $-.51^{* *}$ & -.21 & $-.48^{* *}$ & $.85^{* *}$ & $.74^{* *}$ & - & $-41^{* *}$ \\
\hline QSSR & 15 & -.02 & .07 & -.04 & -.05 & .14 & -.01 & -.01 & .09 & $.34^{* *}$ & .14 & $.32^{* *}$ & .01 & $-.48^{* *}$ & $-.24^{*}$ & - \\
\hline
\end{tabular}

Note. Social Skills Interv $=$ Social Skills Interview Script for Teachers-Social Educational Skills; SES = Social Educational Skills; NEP = Negative Educational Practices; CSS = Children's Social Skills; BP = Behavior Problems; QSSR = Questionnaire of Socially Skillful Responses (Teachers' version); 1 = Communicating and negotiating; 2 = Expressing feelings and coping; $3=$ Feeling well; 4 = Total SES; $5=$ Not active skillful; $6=$ Not passive skillful; $7=$ Feeling bad; $8=$ Total NEP; $9=$ Social availability and cooperation; $10=$ Expressing feelings and coping; $11=$ Total CSS. $12=$ Externalizing Problems; $13=$ Internalizing Problems; $14=$ Total BP; $15=\mathrm{QSSR}$ * The correlation is significant at $p$ value $<.05$. ${ }^{*}$ Correlation is significant at $p$ value $>.01$. $\square$ Girls $(n=57) ; \square$ Boys $(n=56)$.

The results of correlations of preschoolers according to gender presented in Table 1 reveal, for both girls and boys: (1) negative correlations between behavior problems and children's social skills; (2) positive correlations between children's social and educational skills; and (3) positive correlations between negative educational practices and behavior problems. Table 2 presents the correlations among the instruments' categories according to clinical condition. 
Table 2

Analysis of Correlation of Scores Obtained in the Subcategories of the Instruments Completed by Teachers Concerning their Educational Practices with Preschool Students According to Behavior Problems

\begin{tabular}{|c|c|c|c|c|c|c|c|c|c|c|c|c|c|c|c|c|}
\hline & & 1 & 2 & 3 & 4 & 5 & 6 & 7 & 8 & 9 & 10 & 11 & 12 & 13 & 14 & 15 \\
\hline \multirow{4}{*}{$\begin{array}{l}\text { Social } \\
\text { Skills } \\
\text { Interv } \\
\text { (SES) }\end{array}$} & 1 & - & .09 & -.04 & .87 & .16 & -.06 & .09 & .13 & $.45^{* *}$ & $.39^{* *}$ & $.49^{* *}$ & .16 & -.14 & .08 & .06 \\
\hline & 2 & $-.28^{*}$ & - & -.11 & .19 & $.26^{*}$ & .19 & -.02 & .20 & .03 & .14 & .08 & .19 & -.03 & .11 & -.01 \\
\hline & 3 & $.44^{* *}$ & -.16 & - & .01 & -.21 & -.21 & $-.48^{* *}$ & $-.37^{* *}$ & .12 & -.20 & -.01 & -.17 & -.20 & $-.25^{*}$ & $.25^{*}$ \\
\hline & 4 & $.79^{* *}$ & -.04 & $.61^{* *}$ & - & .17 & -.05 & .04 & .13 & $.41^{* *}$ & $.44^{* *}$ & $.48^{* *}$ & .19 & -.10 & .07 & .13 \\
\hline \multirow{4}{*}{$\begin{array}{l}\text { Social } \\
\text { Skills } \\
\text { Interv } \\
\text { (NEP) }\end{array}$} & 5 & $-.24^{*}$ & -.07 & -.02 & -.16 & - & .09 & $.43^{* *}$ & $.89^{* *}$ & -.14 & .16 & -.01 & $.55^{* *}$ & .13 & $.50^{* *}$ & .07 \\
\hline & 6 & -.02 & -.11 & .04 & .15 & $.22^{*}$ & - & $.30^{*}$ & $.36^{* *}$ & -.07 & -.07 & -.09 & .17 & -.08 & .13 & .20 \\
\hline & 7 & -.06 & .03 & -.13 & -.01 & $.35^{* *}$ & $.25^{*}$ & - & $.75^{* *}$ & -.16 & -.03 & -.12 & $.52^{* *}$ & .17 & $.51^{* *}$ & -.04 \\
\hline & 8 & $-.21^{*}$ & -.06 & -.06 & -.11 & $.93^{* *}$ & $.37^{* * *}$ & $.66^{* *}$ & - & -.18 & .09 & -.06 & $.62^{* *}$ & .15 & $.58^{* *}$ & .07 \\
\hline \multirow{3}{*}{$\begin{array}{l}\text { Social } \\
\text { Skills } \\
\text { Interv } \\
\text { (CSS) }\end{array}$} & 9 & .08 & .10 & -.04 & .19 & -.16 & -.12 & $-.27^{*}$ & $-.23^{*}$ & - & $.52^{* *}$ & $.93^{* *}$ & $-.23^{*}$ & $-.54^{* *}$ & $-.44^{* *}$ & $.47^{* *}$ \\
\hline & 10 & .09 & .01 & .13 & $.22^{*}$ & .13 & -.08 & .02 & .10 & .18 & - & $.79^{* *}$ & -.01 & $-.45^{* *}$ & $-.25^{*}$ & $.41^{* *}$ \\
\hline & 11 & .11 & .09 & .03 & $.26^{*}$ & -.06 & -.14 & -.21 & -.14 & $.88^{* *}$ & $.62^{* *}$ & - & -.16 & $-.57^{* *}$ & $-.41^{* *}$ & $.51^{* *}$ \\
\hline \multirow{3}{*}{$\begin{array}{c}\text { Social } \\
\text { Skills } \\
\text { Interv } \\
(\mathrm{BP})\end{array}$} & 12 & -.01 & .05 & .09 & -.09 & $.53^{* *}$ & .12 & $.37^{* *}$ & $.56^{* *}$ & $-.44^{* *}$ & -.07 & $-.39^{* *}$ & - & .08 & $.82^{* *}$ & .01 \\
\hline & 13 & .13 & $-.25^{*}$ & .09 & .09 & $.27^{*}$ & $.45^{* *}$ & $.26^{*}$ & $.35^{* *}$ & $-.52^{* *}$ & $-.24^{*}$ & $-.53^{* *}$ & $.38^{* *}$ & - & $.61^{* * *}$ & $-.56^{* *}$ \\
\hline & 14 & .10 & -.14 & .09 & .02 & $.29^{* *}$ & $.34^{* *}$ & $.36^{* *}$ & $.40^{* *}$ & $-.57^{* *}$ & $-.22^{*}$ & $-.56^{* *}$ & $.78^{* *}$ & $.71^{* *}$ & - & $-.27^{*}$ \\
\hline QSSR & 15 & $-.25^{*}$ & .07 & -.09 & -.19 & -.01 & .09 & -.12 & -.04 & $.30^{* *}$ & -.04 & $.22^{*}$ & -.04 & $-.28^{*}$ & -.05 & - \\
\hline
\end{tabular}

Note. Social Skills Interv $=$ Social Skills Interview Script for Teachers-Social Educational Skills; SES = Social Educational Skills; $\mathrm{NEP}=$ Negative Educational Practices; CSS = Children's Social Skills; BP = Behavior Problems; QSSR = Questionnaire of Socially Skillful Responses (Teachers' version). $1=$ Communicating and negotiating; $2=$ Expressing feelings and coping; $3=$ Feeling well; $4=$ Total SES; $5=$ Not active skillful; $6=$ Not passive skillful; $7=$ Feeling bad; $8=$ Total NEP; $9=$ Social availability and cooperation; $10=$ Expressing feelings and coping; $11=$ Total CSS; $12=$ Externalizing Problems; $13=$ Internalizing Problems; $14=$ Total BP; $15=$ QSSR. *The correlation is significant at $p$ value $<.05$. ${ }^{* *}$ Correlation is significant at $p$ value $>.01$. $\square$ Clinical group $(n=74)$; $\square$ Non-clinical group $(n=96)$.

The results concerning the correlations of both the clinical and non-clinical groups for behavior problems among preschoolers (Table 2) reveal for both groups (1) positive correlations between negative educational practices and behavior problems; (2) positive correlations between positive social educational skills and children's skills; and (3) negative correlations between behavior problems and children's social skills. There is also a negative correlation between social educational skills, such as communicating and negotiating, and the social skills repertoire measured by the Questionnaire of Social Skill Responses.

The results of correlations concerning school children (Table 3) show that both groups presented (1) positive correlations between children's social skills and educational skills; (2) negative correlations between behavior problems and children's social skills; (3) positive correlations between behavior problems and negative educational practices; and (4) negative correlations between children's social skills and negative educational practices. Only for the boys we found (1) negative correlations between negative educational practices and the subcategory "feeling well" (social educational skill) and (2) positive correlations between behavior problems and social educational skills.
Finally, data concerning the school children divided into clinical and non-clinical groups for behavior problems, presented in Table 4, show positive correlations for both groups between (1) social educational skills and children's social skills; (2) behavior problems and social educational skills; and (3) behavior problems and negative educational practices. No negative correlations were found in the group of non-clinical school children with social educational skills or negative educational practices. Positive correlations were found in the clinical group between negative educational practices and the subcategory "feeling well" and negative correlations between behavioral problems and children's social skills.

In summary, correlations were found for all groups, namely (1) positive correlations between social educational skills and children's skills; (2) negative correlations between behavior problems and negative educational practices; and (3) negative correlations between behavior problems and children's social skills. Positive correlations between educational social skills and behavior problems stand out in both the clinical and non-clinical school-aged boys. The clinical group of school-aged boys presented negative correlations between negative educational practices and the subcategory "feeling well" from the social educational skills category. 
Table 3

Analysis of Correlation of Scores Obtained in the Subcategories of the Instruments Completed by Teachers Concerning their Educational Practices with School Students According to Gender

\begin{tabular}{|c|c|c|c|c|c|c|c|c|c|c|c|c|c|c|c|c|}
\hline & & 1 & 2 & 3 & 4 & 5 & 6 & 7 & 8 & 9 & 10 & 11 & 12 & 13 & 14 & 15 \\
\hline \multirow{4}{*}{$\begin{array}{l}\text { Social } \\
\text { Skills } \\
\text { Interv } \\
\text { (SES) }\end{array}$} & 1 & - & -.00 & $.21 *$ & $.88^{* *}$ & $.21 *$ & -.06 & .09 & $.17 *$ & .14 & $.16^{*}$ & $.18^{*}$ & $31 * *$ & $.24 * *$ & $.35 * *$ & -.10 \\
\hline & 2 & $-.25^{*}$ & - & -.11 & $.45^{* *}$ & .06 & .01 & .10 & .08 & $.22 *$ & $.32 * *$ & $.31 * *$ & .04 & .11 & .09 & -.02 \\
\hline & 3 & .03 & -.01 & - & $.24 * *$ & $-.21 *$ & $-.28 * *$ & $-.42 * *$ & $-.34 * *$ & $.23 * *$ & $.25^{* *}$ & $.28 * *$ & $-.20 *$ & -.02 & $-.17 *$ & .04 \\
\hline & 4 & $.87 * *$ & .22 & .18 & - & $.17 *$ & -.09 & .06 & .13 & $.26^{* *}$ & $.33 * *$ & $.35^{* *}$ & $.24 * *$ & $.23^{* *}$ & $.30 * *$ & -.07 \\
\hline \multirow{4}{*}{$\begin{array}{l}\text { Social } \\
\text { Skills } \\
\text { Interv } \\
\text { (NEP) }\end{array}$} & 5 & .10 & .01 & -.12 & .08 & - & $.18^{*}$ & $.50 * *$ & $.92 * *$ & -.13 & .03 & -.08 & $.50 * *$ & $.29 * *$ & $.54 * *$ & $-.17 *$ \\
\hline & 6 & .03 & -.07 & -.14 & -.03 & -.08 & - & $.32 * *$ & $.37 * *$ & -.12 & .12 & -.04 & $.29 * *$ & .05 & $.27 * *$ & -.02 \\
\hline & 7 & .09 & -.05 & $-.50 * *$ & -.01 & $.36^{* *}$ & -.07 & - & $.78 * *$ & $-.22 * *$ & -.01 & $-.16^{*}$ & $.48^{* *}$ & $.28 * *$ & $.53 * *$ & $-.25 * *$ \\
\hline & 8 & .12 & -.02 & $-.34 * *$ & .05 & $.89 * *$ & -.02 & $.74 * *$ & - & $-.19 *$ & .03 & -.12 & $.58 * *$ & $.33^{* *}$ & $.62 * *$ & $-.22 * *$ \\
\hline \multirow{3}{*}{$\begin{array}{l}\text { Social } \\
\text { Skills } \\
\text { Interv } \\
\text { (CSS) }\end{array}$} & 9 & $.25^{*}$ & .01 & $.26^{*}$ & $.29 *$ & $-.24 *$ & -.01 & -.17 & $-.26^{*}$ & - & $.31 * *$ & $.89 * *$ & $-.31 * *$ & $-.28 * *$ & $-.36 * *$ & $.50 * *$ \\
\hline & 10 & $.39 * *$ & .07 & .11 & $.43 * *$ & -.11 & .04 & -.10 & -.12 & .13 & - & $.70 * *$ & -.01 & $-.16^{*}$ & -.06 & $.19^{*}$ \\
\hline & 11 & $.40 * *$ & .06 & $.26^{*}$ & $.46^{* *}$ & $-.23 *$ & .01 & -.19 & $-.26^{*}$ & $.86^{* *}$ & $.61 * *$ & - & $-.24 * *$ & $-.28 * *$ & $-.30 * *$ & $.46^{* *}$ \\
\hline \multirow{3}{*}{$\begin{array}{c}\text { Social } \\
\text { Skills } \\
\text { Interv } \\
\text { (BP) }\end{array}$} & 12 & .04 & -.12 & .06 & .01 & $.61^{* *}$ & -.06 & .21 & $.53 * *$ & -.04 & -.0 & -.05 & - & $.32 * *$ & $.89 * *$ & $-.29 * *$ \\
\hline & 13 & .19 & .07 & $-.34 * *$ & .17 & $.48^{* *}$ & -.08 & $.33 * *$ & $.50 * *$ & $-.30 *$ & -.16 & $-.32 * *$ & $.31 * *$ & - & $.67 * *$ & $-.49 * *$ \\
\hline & 14 & .13 & -.04 & -.15 & .09 & $.69^{* *}$ & -.09 & $.37 * *$ & $.67^{* *}$ & $-.23 *$ & -.13 & $-.24^{*}$ & $.82 * *$ & $.78^{* *}$ & - & $-.47 * *$ \\
\hline QSSR & 15 & .04 & -.20 & $.28 *$ & -.01 & $-.24 *$ & .05 & $-.30 *$ & $-.31 * *$ & $.43 * *$ & .21 & $.45^{* *}$ & -.03 & $-.58 * *$ & $-.38 * *$ & - \\
\hline
\end{tabular}

Note. Social Skills Interv: Social Skills Interview Script for Teachers-Social Educational Skills; SES: Social Educational Skills; NEP: Negative Educational Practices; CSS: Children's Social Skills; BP: Behavior Problems; QSSR: Questionnaire of Socially Skillful Responses (Teachers' version). 1 = Communicating and negotiating; $2=$ Expressing feelings and coping; 3 = Feeling well; $4=$ Total SES; $5=$ Not active skillful; $6=$ Not passive skillful; $7=$ Feeling bad; $8=$ Total NEP; $9=$ Social availability and cooperation; $10=$ Expressing feelings and coping; $11=$ Total CSS; $12=$ Externalizing Problems; $13=$ Internalizing Problems; $14=$ Total BP; $15=$ QSSR. *The correlation is significant at $p$ value $<.05$. ${ }^{*}$ Correlation is significant at $p$ value $>.01 . \square$ Girls $(n=57)$; $\square$ Boys $(n=113)$.

Table 4

Analysis of Correlation of Scores Obtained in the Subcategories of the Instruments Completed by Teachers Concerning their Educational Practices with School Students According to Behavior Problems

\begin{tabular}{|c|c|c|c|c|c|c|c|c|c|c|c|c|c|c|c|c|}
\hline & & 1 & 2 & 3 & 4 & 5 & 6 & 7 & 8 & 9 & 10 & 11 & 12 & 13 & 14 & 15 \\
\hline Social & 1 & - & .09 & -.04 & $.87 * *$ & .16 & -.06 & .09 & .13 & $.45^{* *}$ & $.39 * *$ & $.49 * *$ & .16 & -.14 & .08 & .06 \\
\hline Skills & 2 & $-.28 *$ & - & -.11 & .19 & $.26^{*}$ & .19 & -.02 & .20 & .03 & .14 & .08 & .19 & -.03 & .11 & -.01 \\
\hline \multirow{2}{*}{$\begin{array}{l}\text { Interv } \\
\text { (SES) }\end{array}$} & 3 & $.44 * *$ & -.16 & - & .01 & -.21 & -.21 & $-.48 * *$ & $-.37 * *$ & .12 & -.20 & -.01 & -.17 & -.20 & $-.25^{*}$ & $.25^{*}$ \\
\hline & 4 & $.79 * *$ & -.04 & $0.61 * *$ & - & .17 & -.05 & .04 & .13 & $.41 * *$ & $.44 * *$ & $.48 * *$ & .19 & -.10 & .07 & .13 \\
\hline \multirow{4}{*}{$\begin{array}{l}\text { Social } \\
\text { Skills } \\
\text { Interv } \\
\text { (NEP) }\end{array}$} & 5 & $-.24 *$ & -.07 & -.02 & -.16 & - & .09 & $.43^{* *}$ & $.89 * *$ & -.14 & .16 & -.01 & $.55^{* *}$ & .13 & $.50 * *$ & .07 \\
\hline & 6 & -.02 & -.11 & .04 & .15 & $.22 *$ & - & $.30 *$ & $.36^{* *}$ & -.07 & -.07 & -.09 & .17 & -.08 & .13 & .2 \\
\hline & 7 & -.06 & .03 & -.13 & -.01 & $.35^{* *}$ & $.25^{*}$ & - & $.75^{* *}$ & -.16 & -.03 & -.12 & $.52 * *$ & .17 & $.51^{* *}$ & -.04 \\
\hline & 8 & $-.21^{*}$ & -.06 & -.06 & -.11 & $.93^{* *}$ & $.37^{* *}$ & $.66^{* *}$ & - & -.18 & .09 & -.06 & $.62 * *$ & .15 & $.58 * *$ & .07 \\
\hline \multirow{3}{*}{$\begin{array}{l}\text { Social } \\
\text { Skills } \\
\text { Interv } \\
(\mathrm{CSS})\end{array}$} & 9 & .08 & .10 & -.04 & .19 & -.16 & -.12 & $-.27 *$ & $-.23^{*}$ & - & $.52 * *$ & $.93 * *$ & $-.23^{*}$ & $-.54 * *$ & $-.44 * *$ & $.47 * *$ \\
\hline & 10 & .09 & .01 & .13 & $.22 *$ & .13 & -.08 & .02 & .10 & .18 & - & $.79 * *$ & -.01 & $-.45^{* *}$ & $-.25^{*}$ & $.41 * *$ \\
\hline & 11 & .11 & .09 & .03 & $.26^{*}$ & -.06 & -.14 & -.21 & -.14 & $.88^{* *}$ & $.62 * *$ & - & -.16 & $-.57 * *$ & $-.41 * *$ & $.51 * *$ \\
\hline \multirow{3}{*}{$\begin{array}{l}\text { Social } \\
\text { Skills } \\
\text { Interv } \\
\text { (BP) } \\
\end{array}$} & 12 & -.01 & -.05 & .09 & -.09 & $.53 * *$ & .12 & $.37 * *$ & $.56^{* *}$ & $-.44 * *$ & -.07 & $-.39 * *$ & - & .08 & $.82 * *$ & .01 \\
\hline & 13 & .13 & $-.25^{*}$ & .09 & .09 & $.27 *$ & $.45^{* *}$ & $.26^{*}$ & $.35^{* *}$ & $-.52 * *$ & $-.24 *$ & $-.53 * *$ & $.38 * *$ & - & $.61^{* *}$ & $-.56^{* *}$ \\
\hline & 14 & .10 & -.14 & .09 & .02 & $.29 * *$ & $.34 * *$ & $.36^{* *}$ & $.40 * *$ & $-.57 * *$ & $-.22 *$ & $-.56^{* *}$ & $.78^{* *}$ & $.71^{* *}$ & - & $-.27 *$ \\
\hline QSSR & 15 & $-.25^{*}$ & .07 & -.09 & -.19 & -.01 & .09 & -.12 & -.04 & $.30^{* *}$ & -.04 & $.22 *$ & -.04 & $-.28 *$ & -.05 & - \\
\hline
\end{tabular}

Note. Social Skills Interv = Social Skills Interview Script for Teachers-Social Educational Skills; SES = Social Educational Skills; NEP=Negative Educational Practices; CSS = Children's Social Skills; BP = Behavior Problems; QSSR = Questionnaire of Socially Skillful Responses (Teachers' version). 1 = Communicating and negotiating; $2=$ Expressing feelings and coping; $3=$ Feeling well; $4=$ Total SES; $5=$ Not active skillful; $6=$ Not passive skillful; $7=$ Feeling bad; $8=$ Total NEP; $9=$ Social availability and cooperation; $10=$ Expressing feelings and coping; $11=$ Total CSS; $12=$ Externalizing Problems; $13=$ Internalizing Problems; $14=$ Total BP; $15=$ QSSR. *The correlation is significant at $p$ value $<.05 .{ }^{* *}$ Correlation is significant at $p$ value $>0.01$. $\square$ Non clinical group $(n=74)$; $\square$ Clinical group $(n=96)$. 
Table 5

Results of the Binary Logistic Regression of the Subcategories of the Instruments Completed by the Teachers Concerning their Educational Practices with Preschool and School Children

\begin{tabular}{|c|c|c|c|c|}
\hline & \multirow{2}{*}{ Odds Radio } & \multicolumn{2}{|c|}{ CI 95\% } & \multirow{2}{*}{$p$} \\
\hline & & Lower & Upper & \\
\hline \multicolumn{5}{|l|}{ Preschoolers $(n=113)$} \\
\hline Gender & .25 & .09 & .67 & .01 \\
\hline Social Skills Interview: Behavior Problem & .87 & .80 & .94 & 0 \\
\hline QSSR: Children's Social Skills & 1.1 & 1.04 & 1.16 & 0 \\
\hline \multicolumn{5}{|l|}{ School children $(n=170)$} \\
\hline Social Skills Interview: Social Educational Skills & 1.14 & 1.03 & 1.24 & .01 \\
\hline Social Skills Interview: Negative Educational Practices & .72 & .55 & .94 & .01 \\
\hline Social Skills Interview: Behavior Problem & .85 & .77 & .94 & 0 \\
\hline QSSR: Children's Social Skills & 1.01 & 1.04 & 1.15 & 0 \\
\hline
\end{tabular}

Note. Social Skills Interview = Social Skills Interview Script for Teachers; QSSR = Questionnaire of Socially Skillful Responses Teachers' version.

The results concerning the Binary Logistic Regression for preschool and school children reveal that the independent variables of gender, behavior problems and children's social skills among preschoolers presented significant predictive values for the dependent variable concerning indicators of behavior problems. Social educational skills and negative educational practices, behavior problems and social skills presented significant predictive value for the group of school children. Hence, the behaviors of school children may vary according to differences in educational practices.

\section{Discussion}

Associations between social educational skills and children's skills in both preschool and school children (both according to gender and according to behavior problems) suggest that the more skilled teachers are, the more social skills students develop. From another perspective, the suggestion is that the more skilled students are, the greater the likelihood of obtaining more skilled responses from teachers. The interactions in which social skills are present tend to produce a pleasant and affectionate environment, enabling improved academic and social learning. Such relationships were also evidenced in other studies indicating that positive, close and affectionate relationships are associated with social competence (Baker et al., 2008; Bolsoni-Silva \& Mariano, 2014; Gomes \& Pereira, 2014). Positive educational practices tend to work as a protective factor among children who present some risk regarding their development, such as being a male or presenting clinical scores that indicate behavior problems (O'Connor, Collins, \& Supplee, 2012). The reason is that as teachers perform skillful behaviors (such as saying thanks, greeting, praising), their students can learn through imitation and/or modeling (Baker et al., 2008; Gomes \& Pereira, 2014).
The categories of behavior problems were positively correlated with negative educational practices in all the groups and a significant predictive value was found for school children. This result corroborates the results reported by other studies (Baker et al., 2008; Gomes \& Pereira, 2014) and suggests that a teacher's negative behavior tends to favor even more negative and conflicting interactions, impacting the escalation of behavior problems, colleagues rejection, poor social performance, revealing that there is a bi-directional influence in interactions (Doumen et al., 2008; Zhang \& Sun, 2011). One intriguing finding was the negative association between teachers' communication skills and children's social skills, which is possibly a result of the use of an assertive communication to establish limits, which may lead children to avoid responding, even the most skillful ones. Studies employing direct observation may help explain such a result. Additionally, the negative educational practices of teachers may also be influenced by a coercive culture, which allows punitive behaviors at the expense of assertive or reinforcing behaviors (Castro \& Bolsoni-Silva, 2008; Viecili \& Medeiros, 2002). Teachers usually employ these practices because they present immediate effects, such as suppressing behaviors considered to be inappropriate. These practices, however, trigger collateral effects: fear, anxiety, counter control, flight and avoidance (Viecili \& Medeiros, 2002). Hence, in the face of teachers' aversive stimuli, students tend to manifest behaviors such as tardiness, chatting with friends, become indifferent to explanations, or verbal aggression. Thus, the incorrect use of punishment may strengthen undesired behavior and intensify conflict.

We verified that behavior problems among school children, especially those in the group of clinical boys, in addition to being significantly and positively associated with negative educational practices, were also positively correlated with social educational skills. Social educational skills and negative practices also presented significant values 
among school children in the predictive model for behavior problems indicators. One hypothesis for this finding is the potential incoherence of educational practices in which a child, when manifesting a behavior problem, is sometimes punished and other times reinforced. Additionally, it is possible teachers employ social educational skills, to establish limits for instance, more frequently with boys who present behavior problems. In this sense, the study by Bolsoni-Silva and Mariano (2014) also evidenced inconsistencies in the teachers' educational practices, verifying that sometimes they unintentionally reinforce behavior problems. Another hypothesis (Bolsoni-Silva \& Mariano, 2014) involves the quality of communication, considering when such conversations take place and how the students interpret them. Even if teachers manifest skillful behaviors when dealing with behavior problems, students may see these conversations as scolding and continue responding in an aggressive manner. Hence, even skillful behavior may elicit an effect contrary to what was expected (Bolsoni-Silva \& Mariano, 2014). In this sense, other authors (Z. A. P. Del Prette \& A. Del Prette, 2005; Doumen et al., 2008; Zhang \& Sun, 2011) note that social interactions at school can establish and/or maintain behavior problems and deficits in social skills due to the poor administration of recompense and punishment. Castro and Bolsoni-Silva (2008) and Z. A. P. Del Prette and A. Del Prette (2005) consider that teachers have difficulties to deal with students who present behavior problems and such a deficiency, in addition to reinforcing behavior problems, fails to promote more adaptive alternative models. Still in regard to this finding, concerning the fact educational skills present predictive values for behavior problems only among school children, pedagogical parameters are discussed, as primary education seems to be more demanding in academic and social terms, especially when compared to early child education in which activities are more playful and the emphasis is not on content (Ministério da Educação [MEC], 2009, 2010). The focus during early child education is on social interaction, games, and learning cultural aspects (MEC, 2009). The emphasis on primary school, in turn, is on alphabetization and literacy, in addition to Physical Education, Mathematics, Science, History, and Geography (MEC, 2010), which may explain why educational practices predicted behavior problems only among school children, as reported by Bolsoni-Silva et al. (2010). In addition to what is established in law, the results reported by Pereira et al. (2011) show that children attending early child school tend to present improved academic and social performances because the experiences of early childhood schooling promote the learning of behaviors that facilitate the transition to formal education. Different variables present significant values between preschool and school children, while gender did not remain in the model for school children. This result may suggest that school children are more sensitive to the stimuli presented in the environment, both in the relationships established with teachers and in relation to their own repertoire, while boys, at this point, may have learned to control impulsiveness. Hence, attending early child education may be a protective factor for a child's development, as the challenges faced during formal education may become less complex for children who have already developed their repertoire and are already familiar with school settings.

Empirical studies (Bub et al., 2007; O'Connor et al., 2011) identified changes in the scores concerning behavior problems and in the respective variables that influenced such behaviors over the course of formal education. Among such changes, various researchers (Bolsoni-Silva et al., 2010; O’Connor et al., 2011; Pizato et al., 2014; Silver et al., 2010) report that scores concerning behavior problems decline over the course of education, which is associated with a potential effect of academic and social learning that takes place at school. Thus, through positive interactions, teachers can teach new and alternative skillful behaviors that compete with problematic ones.

Finally, evidence concerning negative correlations found between child social skills and behavior problems found for all groups is discussed. Social skills also stood out in the predictive model for behavior problems among school and preschool children, as such skills may buffer such problems. These results are consistent with other studies (Baker et al., 2008; Silver et al., 2010) indicating that learning and maintaining a repertoire of behavioral problems seems to be inversely proportional to a deficit in social skills (Bolsoni-Silva \& Mariano, 2014; Casali-Robalinho et al., 2015; Patterson et al., 1992). Therefore, interventions and preventive programs focused on behavior problems could emphasize social skills in which children learn alternative behaviors that would compete with problematic ones (Bolsoni-Silva \& Carrara, 2010).

Even though this study presents the limitation of having a single source of data, its findings can support important analyses of the practices of educators and children's behaviors to produce relevant knowledge in the fields addressing development and psychopathology during childhood. Future studies could address larger samples and other contexts while utilizing different methodologies to avoid biases, such as including direct observations in school settings and collecting information from both parents and children.

\section{References}

Achenbach, T. M. (1991). Manual for the Teacher's Report Form and 1991 profile. Burlington, VT: Department of Psychiatry/University of Vermont.

Achenbach, T. M., \& Edelbrock, C. S. (1978). The classification of child psychopathology: A review and analysis of empirical efforts. Psychological Bulletin, 85(6), 1275-1301. doi:10.1037/0033-2909.85.6.1275

Baker, J. A., Grant, S., \& Morlock, L. (2008). The teacherstudent relationship as a developmental context for children with internalizing or externalizing behavior problems. School Psychology Quarterly, 23(1), 3-15. doi:10.1037/1045-3830.23.1.3 
Berry, D., \& O'Connor, E. (2010). Behavioral risk, teacherchild relationships, and social skill development across middle childhood: A child-by-environment analysis of change. Journal of Applied Developmental Psychology, 31(1), 1-14. doi:10.1016/j.appdev.2009.05.001

Bolsoni-Silva, A. T., \& Carrara, K. (2010). Habilidades sociais e análise do comportamento: Compatibilidades e dissensões conceitual-metodológicas [Social skills and behavioral analysis: compatibilities and conceptual and methodological divergences]. Psicologia em Revista, 16(2), 330-350. Retrieved from http://pepsic.bvsalud. org/pdf/per/v16n2/v16n2a07.pdf

Bolsoni-Silva, A. T., Marturano, E. M., \& Loureiro, S. R. (2009). Construction and Validation of the Brazilian Questionário de Respostas Socialmente Habilidosas segundo Relato de Professores (QRSH-RP). Spanish Journal of Psychology, 12(1), 349-359. https://doi. org/10.1017/S1138741600001748

Bolsoni-Silva, A. T., Loureiro, S. R., \& Marturano, E. M. (2016). Roteiro de entrevista de habilidades sociais educativas parentais: RE-HSE-P [Interview Script of Parental Social Educative Skills: RE-HSE-P]. São Carlos, SP: Hogreffe.

Bolsoni-Silva, A. T., \& Mariano, M. L. (2014). Práticas educativas de professores e comportamentos infantis, na transição ao primeiro ano do Ensino Fundamental [Educative practices of teachers and child behavior, the transition to the first year of elementary school]. Estudos e Pesquisas em Psicologia, 14(3), 814-833. Retrieved from http://www.e-publicacoes.uerj.br/index. php/revispsi/article/view/13912

Bolsoni-Silva, A. T., Marturano, E. M., \& Freiria, R. L. B. (2010). Indicativos de problemas de comportamento e de habilidades sociais em crianças: Um estudo longitudinal [Children's behavior problems and social skills: A longitudinal study]. Psicologia: Reflexão e Crítica, 23(3), 506-515. doi:10.1590/S010279722010000300011

Bordin, I. A., Rocha, M. M., Paula, C. S., Teixeira, M. C. T. V., Achenbach, T. M., Rescorla, L. A., \& Silvares, E. F. M. (2013). Child Behavior Checklist (CBCL), Youth Self-Report (YSR) and Teacher's Report Form (TRF): An overview of the development of the original and Brazilian versions. Cadernos de Saúde Pública, 29(1), 13-28. doi:10.1590/S0102-311X2013000100004

Bray, C. T., \& Leonardo, N. S. T. (2011). As queixas escolares na compreensão de educadoras de escolas públicas e privadas [The school complaints in the understanding of educators from public and private schools]. Psicologia Escolar e Educacional, 15(2), 251-261. doi:10.1590/ S1413-85572011000200007
Bub, K. L., McCartney, K., \& Willett, J. B. (2007). Behavior problem trajectories and first-grade cognitive ability and achievement skills: A latent growth curve analysis. Journal of Educational Psychology, 99(3), 653670. doi:10.1037/0022-0663.99.3.653

Buyse, E., Verschueren, K., Doumen, S., Van Damme, J., \& Maes, F. (2008). Classroom problem behavior and teacher-child relationships in kindergarten: The moderating role of the classroom climate. Journal of School Psychology, 46, 367-391. DOI: 10.1016/j. jsp.2007.06.009

Casali-Robalinho, I. G., Del Prette, Z. A. P., \& Del Prette, A. (2015). Habilidades sociais como preditoras de problemas de comportamento em escolares [Social skills as predictors of problem behavior in school children]. Psicologia: Teoria e Pesquisa, 31(3), 321-330. doi:10.1590/0102-37722015032110321330

Castro, A. B., \& Bolsoni-Silva, A. T. (2008). Habilidades sociais na educação: Relações entre concepções e práticas docentes na educação infantil. [Social skills in education: relationships between conceptions and teaching practices in early childhood education]. In V. L. M. F. Capellini \& R. M. Manzoni (Orgs.), Políticas públicas, práticas pedagógicas e ensino-aprendizagem: Diferentes olhares sobre o processo educacional (pp. 296-311). São Paulo, SP: Cultura Acadêmica.

Del Prette, Z. A. P., \& Del Prette, A. (2005). Psicologia das habilidades sociais na infância: Teoria e prática [Psychology of social skills in childhood: Theory and practice]. Petrópolis, RJ: Vozes.

Doumen, S., Verschueren, K., Buyse, E., Germeijs, V., Luyckx, K., \& Soenens, B. (2008). Reciprocal relations between teacher-child conflict and aggressive behavior in kindergarten: A three-wave longitudinal study. Journal of Clinical Child \& Adolescent Psychology, 37(3), 588-599. doi:10.1080/15374410802148079

Gomes, R. M. S., \& Pereira, A. S. (2014). Influence of age and gender in acquiring social skills in Portuguese preschool education. Psychology, 5(2), 99-103. doi:10.4236/ psych.2014.52015

Guerra, B. T., Rovaris, J. A., Mariano, M., Guidugli, P. M., Rosanti, S., \& Bolsoni-Silva, A. T. (2015). Análise das queixas da rede municipal encaminhadas para a educação especial [Analysis of complaints of municipal directed network submitted to special education]. Psicologia Escolar e Educacional, 19(2), 321-328. doi:10.1590/2175-353920150192841

Kettler, R. J., Elliott, S. N., Davies, M., \& Griffin, P. (2011). Testing a multi-stage screening system: Predicting performance on Australia's national achievement test using teachers' ratings of academic and social behaviors. School Psychology International, 33(1), 93-111. doi: $10.1177 / 0143034311403036$ 
Kim, M.-J., Doh, H.-S., Hong, J. S., \& Choi, M.-K. (2011). Social skills training and parent education programs for aggressive preschoolers and their parents in South Korea. Children and Youth Services Review, 33(6), 838-845. doi:10.1016/j.childyouth.2010.12.001

Mariano, M. L. (2011). Análise de práticas educativas de professores na interação com alunos com e sem problemas de comportamentos [Analysis of educational practices of teachers in the interaction among students with and without behavioral problems]. (Dissertação de mestrado). Retrieved from https://repositorio.unesp.br/ bitstream/handle/11449/97502/mariano_ml_me bauru. pdf? sequence $=1 \&$ isAllowed $=\mathrm{y}$

Ministério da Educação. Conselho Nacional de Educação. Câmara de Educação Básica. (2009, 18 de dezembro). Resolução No. 5, de 17 de dezembro de 2009. Fixa as Diretrizes Curriculares Nacionais para a Educação Infantil. Diário Oficial da União, seção 1.

Ministério da Educação. Conselho Nacional de Educação. Câmara de Educação Básica. (2010, 15 de dezembro). Resolução No. 7, de 14 de dezembro de 2010. Fixa Diretrizes Curriculares Nacionais para o Ensino Fundamental de 9 (nove) anos. Diário Oficial da União, seção 1.

O’Connor, E. E., Collins, B. A., \& Supplee, L. (2012). Behavior problems in late childhood: The roles of early maternal attachment and teacher-child relationship trajectories. Attachment \& Human Development, 14(3), 265-288. doi: 10.1080/14616734.2012.672280

O’Connor, E. E., Dearing, E., \& Collins, B. A. (2011). Teacherchild relationship and behavior problem trajectories in elementary school. American Educational Research Journal, 48(1), 120-162. doi:10.3102/0002831210365008

Patterson, G. R., Reid, J. B., \& Dishion, T. J. (1992). Antisocial boys. Eugene, OR: Castalia.

Pereira, M. T., Marturano, E. M., Gardinal-Pizato, E. C., \& Fontaine, A. M. G. (2011). Possíveis contribuições da educação infantil para o desempenho e a competência social de escolares [Possible contributions of early childhood education for performance and social competence of students]. Psicologia Escolar e Educacional, 15(1), 101109. doi:10.1590/S1413-85572011000100011

Picado, J. R., \& De Rose, T. M. S. (2009). Acompanhamento de pré-escolares agressivos: Adaptação na escola e relação professor-aluno. Psicologia: Ciência e Profissão, 29(1), 132 -145. doi.org/10.1590/S1414-98932009000100011

Pizato, E. C. G., Marturano, E. M., \& Fontaine, A. M. G. V. (2014). Trajetórias de habilidades sociais e problemas de comportamento no ensino fundamental: Influência da educação infantil [Trajectories of social skills and behavior problems in primary school: Influence of early childhood education]. Psicologia: Reflexão e Crítica, 27(1), 189-197. doi:10.1590/S0102-79722014000100021
Reinke, W. M., Eddy, J. M., Dishion, T. J., \& Reid, J. B. (2013). Joint trajectories of symptoms of disruptive behavior problems and depressive symptoms during early adolescence and adjustment problems during emerging adulthood. Journal of Abnormal Child Psychology, 40(7), 1123-1136. doi:10.1007/s10802-012-9630-y

Silver, R. B., Measelle, J. R., Armstrong, J. M., \& Essex, M. J. (2010). The impact of parents, child care providers, teachers, and peers on early externalizing trajectories. Journal of School Psychology, 48(6), 555-583. doi:10.1016/j. jsp.2010.08.003

Viecili, J., \& Medeiros, J. G. (2002). A coerção e suas implicações na relação professor-aluno. Psico-USF, 7(2), 229-238. doi:10.1590/S1413-82712002000200012

Zhang, X., \& Sun, J. (2011). The reciprocal relations between teachers' perceptions of children's behavior problems e teacher-child relationships in the first preschool year. The Journal of Genetic Psychology, 172(2), 176-198. doi:10.10 $80 / 00221325.2010 .528077$

Marilia Mariano holds a M.Sc. from the Universidade Estadual Paulista.

Alessandra Turini Bolsoni-Silva is an Associate Professor of the Universidade Estadual Paulista.

Received: Mar. 07, 2016

1st Revision: May. 19, 2016

Approved: Oct. 25, 2016

How to cite this article:

Mariano, M., \& Bolsoni-Silva, A. T. (2018). Social interactions between teachers and students: A study of associations and predictions. Paidéia (Ribeirão Preto), 28, e2816. doi: http://dx.doi.org/10.1590/1982-4327e2816 